\title{
The Diffusion of Development: Along Genetic or Geographic Lines?
}

\author{
Douglas L. Campbell ${ }^{\mathbb{I}}$ \\ New Economic School (NES)
}

\author{
Ju Hyun Pyun ${ }^{\S}$ \\ Korea University Business School
}

August 2014

\begin{abstract}
Why are some peoples still poor? Recent research suggests that a society's "genetic distance"-a measure of the time elapsed since two populations had common ancestry-to the United States is a significant predictor of development even after controlling for an ostensibly exhaustive list of geographic, historical, religious and linguistic variables. We find, by contrast, that the correlation of genetic distance from the US and GDP per capita disappears with the addition of controls for geography including distance from the equator and a dummy for sub-Saharan Africa.
\end{abstract}

Keywords: Genetic Distance, Economic Development, Geography, Climatic Similarity JEL Classification: O10, O33, O49

\footnotetext{
II Also affiliated with the HSE-NES International Laboratory of Russian Economic History, e-mail: dolcampb@gmail.com.

${ }^{\S}$ Korea University Business School, 145 Anamr-Ro, Seongbuk-Gu, Seoul 136-701, Korea, Email: jhpyun@korea.ac.kr.
} 


\section{Introduction}

Why are some peoples still poor? Economists have begun to investigate the role of genetics in the wealth of nations. One prominent example is Spolaore and Wacziarg (2009) - henceforth SW - which argues that the revolution in technological innovation which began in Lancashire cotton textiles circa 1760 spiraled outwards first to immediate locales, then to the whole of Britain, soon to the entire English-speaking world, and finally to other culturally and genetically similar peoples of the world. ${ }^{1}$ Today, with the United States at the forefront of the world technological hierarchy, SW find that distance to the United States, measured geographically, culturally, and genetically, is a determinant of a society's level of technology and development.

The authors argue that the significance of their genetic distance variable, a measure based on the time elapsed since two societies existed as a single panmictic population developed by Cavalli-Sforza et al. (1994), does not imply any direct influence of specific genes on income. Instead they argue that genetic distance proxies a divergence in traits "biologically and/or culturally" which provide barriers to the diffusion of technology. SW report that genetic distance "has a statistically and economically significant effect on income differences across countries, even controlling for measures of geographical distance, climatic differences, transportation costs, and measures of historical, religious, and linguistic distance." ${ }^{2}$ Were the impact of genetic distance on development robust to an exhaustive array of geographic and other barriers, it could be construed as evidence in favor of a direct impact of genetic distance from the US on income. This provocative result would be interesting and important, but it would also be surprising given that genetic distance to the US appears to be strongly correlated with geographic factors (see the world map in Fig. 1 and Table 1). Continent dummies alone can explain nearly $70 \%$ of the variation in genetic distance (versus a still considerable $56 \%$ of the variation in income), and a fuller set of geographic variables explain $86 \%$ of the variation in genetic distance (vs. $72 \%$ of income $)^{3}$.

\section{[Insert Fig. 1]}

\section{[Insert Table 1]}

We find that the evidence offered in support of the theory that genetic distance predicts GDP per capita is sensitive to geographic controls, including latitude and a dummy variable for

\footnotetext{
${ }^{1}$ Three other examples are Spolaore and Wacziarg (2013 and 2014), who use the same genetic data and make a similar argument with technology adoption, and Ashraf and Galor (2011), who look at ethnic diversity.

2 Spolaore and Wacziarg (2009), p. 469.

${ }^{3}$ These variations come from additional regressions of genetic distance on geographic variables. The results are available on the authors webpages.
} 
sub-Saharan Africa. Our findings are consistent with the theory that the technologies developed during the Industrial Revolution diffused first to other temperate regions of the world, where European agricultural technology could be deployed and where the disease environment was most favorable to European people and their institutions, technology, seeds, animals and even germs. This is the theory developed by a long line of scholars, including Crosby (1972), Kamarck (1976), Diamond (1992), Sachs (2001), and Gallup, Mellinger, and Sachs (1999), who all stress the importance of climatic similarity for the diffusion of various technologies. ${ }^{4}$ In a world with trade costs, where the stability of GDP per capita rankings across decades implies that history matters, and where Malthusian forces have certainly been a strong historically and are debatably still at play in some developing countries (see Clark, 2008), the nature of agricultural technology diffusion and the historical disease environment will necessarily carry outsized importance for development. And regardless of the mechanism, it has long been known that countries near the equator tend to be less developed. SW themselves argue for the inclusion of latitude as a control and express legitimate concern that sub-Saharan Africa may be driving their results, yet they do not control for either in their regressions. ${ }^{5}$

In related research, Giuliano, Spilimbergo, and Tonon (2006, 2013) find that genetic distance does not explain trade flows within Europe after controlling for various geographic measures. Angeles (2012) shows that SW's genetic distance proxy is sensitive to the inclusion of 12 additional linguistic, religious, colonial, geographic and another genetic control (percentage of population with European ancestry, not counting mestizos). While these papers also argue against a role of genetics in economic development, the former only considers trade flows and is only applied to the relatively homogenous gene pool of Europe while the latter replaces one genetic variable with another. ${ }^{6}$

\section{Empirics}

We have reproduced the baseline result from SW's Table 1, which estimates the following equation:

\footnotetext{
${ }^{4}$ For example, Crosby (1972) notes that European people, plants, animals, and germs all colonized areas of the world with climates most similar to Europe (which he terms "Neo-Europes"), while Diamond (1992) argues that both diseases and agricultural technology spreads more easily east-to-west, helping to give the natives of the relatively large Eurasian landmass an advantage over more isolated areas (Africa or Australasia) and over those living in continents with a north-to-south axis such as the Americas. Kamarck (1976) discusses the extreme difficulty of transplanting agricultural technologies from temperate regions to the tropics.

${ }^{5}$ Spolaore and Wacziarg (2009), p. 501.

${ }^{6}$ The 2006 version of Giuliano et al. considers incomes, the 2013 version does not. Riahi (2013) argues that historical settler mortality explains both genetic distance and incomes.
} 


$$
\log y_{i}=\alpha+\beta \cdot \operatorname{gen}_{i, U S}+\mathrm{X}_{i,(U S)} \cdot \gamma+G E O_{i} \cdot \delta+\varepsilon_{i},
$$

where $\log y_{i}$ is the $\log$ of country i's GDP per capita in 1995, gen $_{i, U S}$ is the genetic distance to the US from country $\mathrm{i}$, and $\mathrm{X}_{i,(U S)}$ are vectors of geographic controls from SW. $\mathrm{X}_{i,(U S)}$ includes absolute longitudinal and latitudinal difference from the US, distance from the US, contiguity with the US and a dummy for sharing an ocean with the US, and being an island or landlocked. $G E O_{i}$ are important climatic and geographic difference controls omitted in $\mathrm{SW}$, including distance from the equator and a dummy for sub-Saharan Africa.

In column (1) of Table 2, we find that "genetic distance to the US," measured as the amount of time elapsed since the populations in these countries separated, is a significant predictor of income per capita even after controlling for various measures of physical distance. ${ }^{7}$ Yet, column (1) does not contain any variables which denote differences in climatic endowments. "Absolute difference in latitude" from the US is included, but "absolute difference in absolute latitude"-distance from the equator ${ }^{8}$-is not. The reason why the latter is the appropriate control should be clear: although the Southern Cone countries, South Africa, and Australasia all have very large absolute differences in latitudes with the US, they have similar climates owing to their similar absolute latitudes with Europe and the United States.

\section{[Insert Table 2]}

Fig. 2.A displays the nonlinear relationship between income and absolute difference in latitude with the US that SW considers as their one of main geographic controls, while the strong relationship between income and distance from the equator is readily apparent in Fig. 2.B. SW themselves write that latitude could affect income directly, or via technology diffusion, and so is a relevant control, yet they do not include distance from the equator as a control in their primary results in SW's Table 1 (p.488). By including distance from equator in column (2), the marginal effect of genetic distance on income difference decreases by $33 \%$ although the genetic distance coefficient is still significant.

\section{[Insert Fig. 2]}

\footnotetext{
${ }^{7}$ Our sample size is slightly larger than SW's as their original sample is not publicly available and could not be acquired, and there is one variable, freight rate to the northeastern US, which we could not get as the original website listed as the source in SW appears to be no longer operable. This variable was not significant in SW, and eliminating all of SW's other controls do not change our results (Table 1, Column 4). Our replicated coefficient is slightly larger than that in SW -- -13.5 vs. -12.5 .

${ }^{8}$ Hall and Jones (1999) also find a high correlation between distance from equator and income per capita although they interpret latitude as a proxy for institutional quality because it is highly correlated with "Western influence," rather than as a geographic or climatic variable.
} 
In addition, Fig. 2.B captures heterogeneity of the geographic region of sub-Saharan Africa. In Fig. 2.B, the fact that most of sub-Saharan Africa is very poor and located very close to the equator is also apparent. It might be that "genetic distance" explains why it is that subSaharan Africa is poor or why latitude is so highly correlated with development-that Europeans settled in areas with climates similar to Europe, and these places are now developed owing, according to SW, either to the ease with which European technologies were able to diffuse to populations with similar genetic endowments, or to the special characteristics of those endowments. ${ }^{9}$ In column (3) of Table 2 , however, when we include a dummy for the 41 subSaharan African nations in our sample-the very first specification we tried-the coefficient on genetic distance falls substantially, rendering the results insignificant. Thus genetic distance to the US does not seem to help explain poverty in Africa or in the tropics. ${ }^{10}$

SW presciently express concern that sub-Saharan Africa may be driving their results, but instead of including it as a control, as is standard in the cross-country growth literature, including Barro (1991), Fisher (1991), Sala-i-Martin (1997) and Lorentzen, McMillan, and Wacziarg $(2008)^{11}$, SW report that their results are robust to excluding sub-Saharan Africa countries in their regressions. ${ }^{12}$ Yet, while sub-Saharan Africa is very poor and distant genetically from the US, within Africa, the richer countries tend to be genetically remote (see Fig. 3). This pattern also holds for other regions such as Asia. In fact, several rich East-Asian nations, such as Japan, Hong Kong, and Singapore, are actually more distant from the US genetically than many very poor sub-Saharan Africa countries, such as Somalia, Ethiopia, and Madagascar (see Fig. 3). Given that evidence within sub-Saharan Africa itself constitutes a clear counterexample, it is legitimate to ask why excluding a group of counterexamples is preferable to including a control for sub-Saharan Africa, as is the standard in the cross-country income regression literature. In addition, SW themselves argue that the impact of genetic distance on income is robust to the inclusion of controls for large geographic regions.

\section{[Insert Fig. 3]}

\footnotetext{
${ }^{9}$ Bloom and Sachs (1998) emphasize the geographic and climatic characteristics of sub-Saharan Africa in determining poor economic performance in the region, arguing that "Sub-Saharan Africa is the far most tropical一in the simple sense of the highest proportions of land and population in the tropics—of the world's major regions." The recent works also consider various causes of poor economic performance of sub-Saharan Africa such as legacy of colonial rules and slave trading, heavy dependence on a small number of primary exports, internal politics and corruption, demographic changes, etc.

${ }^{10}$ One may argue whether or not sub-Saharan Africa dummy represents only geographic factors of the region because sub-Saharan Africa dummy may absorb some of historical, cultural and political factors in the continent. The debate on the interpretation on sub-Saharan Africa dummy is still ongoing. However, we argue that beyond the debate, sub-Saharan Africa dummy should be controlled to show the robustness of the effect of genetics on comparative economic development.

${ }^{11}$ The important point is that the Sahara desert constitutes a barrier, and so is a very relevant control. As the famous sign in Zagora, Morocco says, it takes 52 days to get to Timbuktu by camel (Encyclopedia Brittanica).

${ }^{12}$ Spolaore and Wacziarg (2009), p. 501.
} 
As distance from the equator is an imperfect proxy for climate, when we include a more precise climatic variable, the percentage of each country's land area in the tropics or sub-tropics in column (4), the point estimate falls even further. In column (5), we show that that controlling for the tropics and sub-Saharan Africa alone eliminates the result.

To show robustness, we also try controlling for just two continental dummies - Europe and sub-Saharan Africa. The aforementioned cross-country growth studies conventionally include continent dummies to show the validity of their results. Europe is rich and genetically close to the US, and sub-Saharan Africa is poor and genetically distant from the US. The regression results in column (6) demonstrate that, aside from this observation, the variable genetic distance has no predictive power, as the within-region evidence is not supportive. In Fig. 4 , it can be seen that there is no statistically significant correlation between GDP per capita and genetic distance to the US outside of sub-Saharan Africa and Europe. ${ }^{13}$ Finally, in column (7), when we expand the sample to include 20 additional countries ${ }^{14}$ for which we do not have complete data, and just include controls for Europe, sub-Saharan Africa, Asia and contiguity (effectively a North America dummy), we again find no statistically significant relationship. ${ }^{15}$

\section{[Insert Fig. 4]}

SW also argue that if genetic distance to the US predicts income levels, then the income differential between any two countries should be a function of their relative genetic distance to the US. Thus, SW spend most of their paper presenting pairwise differenced regressions (baseline controls in SW's Table IV) showing that relative genetic distance to the US is correlated with income differences generally. The authors difference GDP per capita at the dyadic pair level for each combination of 137 (145 in our sample) countries, manufacturing 9,316 highly dependent data points (10,296 in our slightly larger sample), and use this as the dependent variable with the regressor of interest now being relative genetic distance to the US. The other regressors are differences in geographic variables for each bilateral observation. It should be noted that if there is no cross-country relationship between genetic distance to the US and income, then it is unlikely that relative genetic distance to the US could predict income

\footnotetext{
${ }^{13}$ In Figure 4, we get a coefficient of -5.3 , but with a standard error of 3.3 .

14 See the note in Table 2.

${ }^{15}$ In the additional appendix, we show additional robustness results including those using alternative measures of genetic distance. Notably, the inclusion of regional controls also renders the impact of genetic distance insignificant even when we exclude sub-Saharan African countries.
} 
differentials. ${ }^{16}$ We include our Table 3 in the interest of being thorough. The following specification is built on SW's pairwise differenced regressions:

$$
\left|\log y_{i}-\log y_{j}\right|=\alpha+\beta \cdot g e n_{i j}^{R}+\mathrm{X}_{i j} \gamma+\rho_{i j}+\varepsilon_{i j}
$$

where $\left|\log y_{i}-\log y_{j}\right|$ is the absolute difference of $\log$ income per capita between countries $i$ and $j$ in 1995, and the relative genetic difference variable is defined as $\operatorname{gen}_{i j}^{R}=\left|\operatorname{gen}_{i, U S}-\operatorname{gen}_{j, U S}\right|$, where gen $_{i, U S}$ is the genetic distance to the US, and $\mathrm{X}_{i j}$ is the vector of absolute difference in other geographic variables between countries $i$ and $j . \rho_{i j}$ are pairwise continent (region) fixed effects, and $\varepsilon_{i j}$ is the error term, which are clustered in two dimensions.

\section{[Insert Table 3]}

We reproduce columns (1) and (2) in Table 2 that benchmark SW's Table IV results. These regressions might appear to support a role for genetic distance in development. However, while SW correctly stress the importance of including continent dummies in their analysis, they include only six regions (Asia, Africa, Europe, North America, Latin America, and Oceania) and did not separate sub-Saharan Africa from Mediterranean North Africa. They included a set of six dummies equal to one if both countries in a pair are on the same region and another set of six dummies equal to one if one country belongs to a given region, and the other not. However, using just 12 dummies for six regional pairings with 21 combinations could be problematic. For example, the average absolute income difference between North America and Europe is much smaller than the sum of the average absolute income difference between North America and all other countries plus the average absolute income difference between Europe and all other countries. SW's method of continental dummies predicts a large income difference between North America and Europe, which causes an upward bias on the coefficient genetic distance to the US.

If instead we separate sub-Saharan Africa from the Mediterranean North African countries, and include a separate dummy for each regional pairing-i.e., a dummy for North America paired with South America, and a separate dummy for South America paired with subSaharan Africa for 28 fixed effects total-then the impact of relative genetic distance shrinks and loses significance. However, including these dummies does not render the "Absolute difference in absolute latitude" or the "Absolute difference in \% of land area in the tropics" variables insignificant in columns (4) and (5), while several of the other geographic controls actually increase in significance.

\footnotetext{
${ }^{16}$ This is because the 9,317 bilateral data points in SW were manufactured using data from just 137 countries. If genetic distance to the US does not predict income levels, then it would be extremely unlikely that, for example, genetic distance relative to Canada could predict income differentials with Canada.
} 


\section{Conclusion}

The results presented above show that genetic distance loses the ability to explain income after the inclusion of geographic controls, including distance from the equator and a sub-Saharan Africa dummy. Our findings provide additional evidence for the importance of climatic endowment and regional dummy variables, if not the exact mechanism by which these variables impact development. Future research should continue to introduce creative variables with the potential to explain why some peoples are poor, and why climatic and geographical similarity has been such a strong force historically—but there is scant evidence that the answer to this mystery lies in our genetic differences.

\section{References}

Angeles, Luis. (2012). 'Is there a Role for Genetics in Economic Development?'Working Papers 2012_02, Business School - Economics, University of Glasgow.

Ashraf, Quamrul and Oded Galor. (2011). 'The 'Out of Africa' Hypothesis, Human Genetic Diversity, and Comparative Economic Development' NBER Working Paper 17216.

Barro, Robert J. (1991). 'Economic Growth in a Cross Section of Countries', Quarterly Journal of Economics, 106, pp. 407-443.

Bloom, David and Jeffrey D. Sachs (1998). "Geography, Demography, and Economic Growth in Africa," Brookings Papers on Economic Activity, 1998:2

Cameron, A. Colin, J. Gelbach and D. Miller. (2011). 'Robust Inference with Multi-way Clustering', Journal of Business and Economic Statistics, 29, pp. 238-249.

Cavalli-Sforza, Luigi L., Paolo Menozzi, and Alberto Piazza. (1994). The History and Geography of Human Genes. Princeton, NJ: Princeton University Press.

Clark, Gregory. (2008). A Farewell to Alms. A Brief Economic History of the World. Princeton, NJ: Princeton University Press.

Crosby, Alfred. (1972). The Columbian Exchange: Biological and Cultural Consequences of 1492. Westport, CT: Greenwood Publishing Company. 
Diamond, Jared. (1992). The Third Chimpanzee: The Evolution and Future of the Human Animal. New York, NY: Harper Collins.

Gallup, John L., Andrew D. Mellinger, and Jeffrey D. Sachs. (1999). ‘Geography and Economic Development', International Regional Science Review, 22, pp. 179-222.

Giuliano, Paola, Antonio Spilimbergo, and Giovanni Tonon. (2006). 'Genetic, Cultural and Geographical Distances', Unpublished, International Monetary Fund.

Giuliano, Paola, Antonio Spilimbergo, and Giovanni Tonon. (2013). 'Genetic Distance, Transportation Costs and Trade', Journal of Economic Geography, Forthcoming.

Fischer, S. (1991). Growth, Macroeconomics, and Development. In NBER Macroeconomics Annual 1991, Volume 6 (pp. 329-379). MIT Press.

Hall, Robert E. and Jones, Charles I. (1999) 'Why Do Some Countries Produce So Much More Out-put Per Worker Than Others?' Quarterly Journal of Economics, 114(1), pp. 83-116.

Kamarck, Andrew. (1976). The Tropics and Economic Development: A Provocative Inquiry in the Poverty of Nations. Baltimore, MD: The Johns Hopkins Press.

Lorentzen, Peter, John McMillan, and Romain Wacziarg. (2008). 'Death and Development', Journal of Economic Growth, 13, pp. 81-124.

Riahi, Ideen. (2013). 'Colonization and Genetics of Comparative Development'. Discussion Papers dp13-11, Department of Economics, Simon Fraser University.

Sachs, Jeffrey D. (2001). 'Tropical Underdevelopment', NBER working paper, No. 8119.

Sala-i-Martin, Xavier X. (1997). 'I Just Ran Two Million Regressions', American Economic Review, 87, pp. 178-183.

Spolaore, Enrico and Romain Wacziarg. (2009). 'The Diffusion of Development', Quarterly Journal of Economics, 124, pp. 469-529.

Spolaore, Enrico \& Romain Wacziarg. (2013). 'How Deep Are the Roots of Economic Development?,' Journal of Economic Literature, American Economic Association, vol. 51(2), pp. 325-69, June.

Spolaore, Enrico and Romain Wacziarg. (2014). 'Long Term Barriers to the International Diffusion of Innovations', Handbook of Economic Growth, in: Handbook of Economic Growth, edition 1, volume 2, chapter 3, pp. 121-176. 
Table 1. Correlation between Key Variables

\begin{tabular}{lcccccc}
\hline & $\begin{array}{c}\text { Log GDP } \\
\text { per capita }\end{array}$ & $\begin{array}{c}\text { Fst Genetic } \\
\text { Distance to } \\
\text { the US, } \\
\text { weighted }\end{array}$ & $\begin{array}{c}\text { Sub- } \\
\text { Saharan } \\
\text { Africa } \\
\text { dummy }\end{array}$ & $\begin{array}{c}\text { Distance } \\
\text { from } \\
\text { Equator }\end{array}$ & $\begin{array}{c}\text { \% of land } \\
\text { area in } \\
\text { tropics and } \\
\text { subtropics }\end{array}$ & $\begin{array}{c}\text { Europe } \\
\text { dummy }\end{array}$ \\
\hline $\begin{array}{l}\text { Log GDP per capita in } \\
1995\end{array}$ & 1 & & & & & \\
$\begin{array}{l}F \text { st genetic distance to the } \\
\text { US, weighted } \\
\text { Sub-Saharan Africa } \\
\text { dummy }\end{array}$ & -0.6107 & 1 & & & & \\
$\begin{array}{l}\text { Distance from Equator } \\
\text { \% of land area in tropics }\end{array}$ & -0.6132 & 0.7693 & & & & \\
and subtropics & -0.5639 & -0.6623 & -0.5378 & & \\
Europe dummy & 0.5390 & -0.5192 & -0.3575 & 0.7169 & -0.4975 & \\
\hline
\end{tabular}


Table 2. Income Level Regressed on Various Geographic Measures, 1995

Dependent variable: log income per capita, 1995

\begin{tabular}{|c|c|c|c|c|c|c|c|}
\hline & $\begin{array}{c}(1) \\
\text { SW's } \\
\text { Baseline } \\
\text { Controls }\end{array}$ & $\begin{array}{c}\text { (2) } \\
\text { Add } \\
\text { Distance } \\
\text { from } \\
\text { equator }\end{array}$ & $\begin{array}{c}\text { (3) } \\
\text { Add } \\
\text { Distance } \\
\text { from } \\
\text { equator } \\
\text { \& sub- } \\
\text { Saharan } \\
\text { Africa } \\
\text { (SSA) } \\
\text { dummy }\end{array}$ & $\begin{array}{c}(4) \\
\text { Add (\%) of } \\
\text { Land Area } \\
\text { in Tropics } \\
\text { and Sub- } \\
\text { Tropics }\end{array}$ & $\begin{array}{c}\text { (5) } \\
\text { Sparse } \\
\text { Controls } \\
\text { (SSA } \\
\text { dummy \& } \\
\text { Climatic } \\
\text { Control) }\end{array}$ & $\begin{array}{c}\text { (6) } \\
\text { Two } \\
\text { Continent } \\
\text { Controls } \\
\text { only }\end{array}$ & $\begin{array}{c}(7) \\
\text { Enlarged } \\
\text { Sample, } \\
\text { with } \\
\text { Continent } \\
\text { Controls }\end{array}$ \\
\hline $\begin{array}{l}F_{\mathrm{ST}} \text { genetic distance to } \\
\text { the US, weighted }\end{array}$ & $\begin{array}{c}-13.28 * * * \\
{[2.061]}\end{array}$ & $\begin{array}{c}-8.924 * * * \\
{[2.276]}\end{array}$ & $\begin{array}{l}-3.301 \\
{[2.729]}\end{array}$ & $\begin{array}{l}-1.261 \\
{[2.876]}\end{array}$ & $\begin{array}{l}-3.176 \\
{[2.724]}\end{array}$ & $\begin{array}{c}-3.12 \\
{[2.521]}\end{array}$ & $\begin{array}{l}-2.778 \\
{[2.207]}\end{array}$ \\
\hline $\begin{array}{l}\text { Absolute difference in } \\
\text { latitude from US }\end{array}$ & $\begin{array}{l}1.811^{* *} \\
{[0.709]}\end{array}$ & $\begin{array}{l}1.085^{*} \\
{[0.605]}\end{array}$ & $\begin{array}{l}1.308 * * \\
{[0.564]}\end{array}$ & $\begin{array}{c}1.643 * * * \\
{[0.619]}\end{array}$ & & & \\
\hline $\begin{array}{l}\text { Absolute difference in } \\
\text { longitude from US }\end{array}$ & $\begin{array}{l}1.130 * * \\
{[0.490]}\end{array}$ & $\begin{array}{c}0.013 \\
{[0.507]}\end{array}$ & $\begin{array}{c}0.051 \\
{[0.462]}\end{array}$ & $\begin{array}{c}0.473 \\
{[0.431]}\end{array}$ & & & \\
\hline $\begin{array}{l}\text { Geodesic distance from } \\
\text { the US (1000s of } \mathrm{km})\end{array}$ & $\begin{array}{c}-0.234 * * \\
{[0.100]}\end{array}$ & $\begin{array}{l}-0.029 \\
{[0.103]}\end{array}$ & $\begin{array}{l}-0.047 \\
{[0.095]}\end{array}$ & $\begin{array}{c}-0.143 \\
{[0.088]}\end{array}$ & & & \\
\hline $\begin{array}{l}=1 \text { for contiguity with the } \\
\text { US }\end{array}$ & $\begin{array}{c}1.200 * * * \\
{[0.212]}\end{array}$ & $\begin{array}{l}0.521^{*} \\
{[0.312]}\end{array}$ & $\begin{array}{l}0.451^{*} \\
{[0.246]}\end{array}$ & $\begin{array}{l}0.487^{*} \\
{[0.272]}\end{array}$ & & & $\begin{array}{c}0.948 * * * \\
{[0.341]}\end{array}$ \\
\hline $\begin{array}{l}=1 \text { if share a common sea } \\
\text { or ocean }\end{array}$ & $\begin{array}{l}-0.407 * \\
{[0.240]}\end{array}$ & $\begin{array}{c}0.024 \\
{[0.253]}\end{array}$ & $\begin{array}{c}-0.102 \\
{[0.251]}\end{array}$ & $\begin{array}{l}-0.135 \\
{[0.252]}\end{array}$ & & & \\
\hline $\begin{array}{l}=1 \text { if the country is an } \\
\text { island }\end{array}$ & $\begin{array}{l}0.656^{* *} \\
{[0.315]}\end{array}$ & $\begin{array}{l}0.660 * * \\
{[0.317]}\end{array}$ & $\begin{array}{c}0.473 \\
{[0.294]}\end{array}$ & $\begin{array}{r}0.528 * * \\
{[0.258]}\end{array}$ & & & \\
\hline $\begin{array}{l}=1 \text { if the country is } \\
\text { landlocked }\end{array}$ & $\begin{array}{l}-0.392 \\
{[0.245]}\end{array}$ & $\begin{array}{c}-0.469 * * \\
{[0.225]}\end{array}$ & $\begin{array}{c}-0.527 * * \\
{[0.226]}\end{array}$ & $\begin{array}{c}-0.517 * * \\
{[0.235]}\end{array}$ & & & \\
\hline $\begin{array}{l}\text { Distance from the } \\
\text { Equator }\end{array}$ & & $\begin{array}{c}0.031 * * * \\
{[0.007]}\end{array}$ & $\begin{array}{c}0.029 * * * \\
{[0.007]}\end{array}$ & & & & \\
\hline $\begin{array}{l}\% \text { of land area in tropics } \\
\text { and sub-tropics }\end{array}$ & & & & $\begin{array}{c}-1.109 * * * \\
{[0.248]}\end{array}$ & $\begin{array}{c}-0.740 * * * \\
{[0.230]}\end{array}$ & & \\
\hline $\begin{array}{l}\text { Sub-Saharan Africa } \\
\text { dummy }\end{array}$ & & & $\begin{array}{c}-0.940 * * * \\
{[0.228]}\end{array}$ & $\begin{array}{c}-1.293 * * * \\
{[0.245]}\end{array}$ & $\begin{array}{c}-1.277 * * * \\
{[0.270]}\end{array}$ & $\begin{array}{c}-1.168 * * * \\
{[0.248]}\end{array}$ & $\begin{array}{c}-1.362 * * * \\
{[0.225]}\end{array}$ \\
\hline Europe dummy & & & & & & $\begin{array}{c}0.985^{* * * *} \\
{[0.199]}\end{array}$ & $\begin{array}{c}0.736 * * * \\
{[0.192]}\end{array}$ \\
\hline Asia dummy & & & & & & & $\begin{array}{c}-0.593 * * \\
{[0.251]}\end{array}$ \\
\hline Constant & $\begin{array}{c}9.774 * * * \\
{[0.267]}\end{array}$ & $\begin{array}{c}8.294 * * * \\
{[0.444]}\end{array}$ & $\begin{array}{c}8.193 * * * \\
{[0.436]}\end{array}$ & $\begin{array}{c}9.480 * * * \\
{[0.287]}\end{array}$ & $\begin{array}{c}9.271 * * * \\
{[0.190]}\end{array}$ & $\begin{array}{c}8.713 * * * \\
{[0.243]}\end{array}$ & $\begin{array}{c}8.951 * * * \\
{[0.232]}\end{array}$ \\
\hline $\begin{array}{l}\text { Observations } \\
R^{2}\end{array}$ & $\begin{array}{c}145 \\
0.447\end{array}$ & $\begin{array}{c}145 \\
0.503\end{array}$ & $\begin{array}{c}145 \\
0.541\end{array}$ & $\begin{array}{c}145 \\
0.552\end{array}$ & $\begin{array}{l}145 \\
0.46\end{array}$ & $\begin{array}{c}145 \\
0.496\end{array}$ & $\begin{array}{c}165 \\
0.489\end{array}$ \\
\hline
\end{tabular}

Notes: 1. Robust Standard errors in parentheses; *significant at 10\%; **significant at 5\%; ***significant at $1 \%$.

2. Genetic distance data from Cavalli-Sforza et al. (1994) via SW (2009). Geographic data is from the Centre d'Etudes Prospectives et d'Informations Internationales (CEPII), Tropics variable from Gallup, Mellinger, and Sachs available at http://www.ciesin.columbia.edu/eidata/, and GDP data is from the World Bank's WDI.

3. The genetic variable (Weighted Fst distance) is the time elapsed between two populations on average.

4. List of countries additionally included in column (6): Antigua and Barbuda, Bahrain, Cape Verde, Comoros, Dominica, Fiji, Grenada, Hong Kong, Kiribati, Malta, Mauritius, St. Christopher and Nevis, St. Lucia, St. Vincent, Seychelles, Singapore, Solomon Islands, Tonga, Vanuatu, Western Samoa 
Table 3. Paired World Income Difference Regression (Two-way Clustering)

Dependent variable: absolute difference of log income per capita between countries $i$ and $j$ in 1995

\begin{tabular}{|c|c|c|c|c|c|}
\hline & \multirow{2}{*}{$\begin{array}{c}(1) \\
\text { Replication } \\
\text { SW's } \\
\text { column 5 in } \\
\text { Table IV }\end{array}$} & \multirow{2}{*}{$\begin{array}{c}\text { (2) } \\
\text { Replication } \\
\text { SW's column } \\
6 \text { in Table IV }\end{array}$} & \multirow[b]{2}{*}{$\begin{array}{c}(3) \\
7 \text { regions } \\
\text { with sub- } \\
\text { Saharan } \\
\text { Africa and } \\
\text { Middle } \\
\text { East\& North } \\
\text { Africa }\end{array}$} & \multirow{2}{*}{$\begin{array}{c}(4) \\
\text { Adding } \\
\text { Abs. } \\
\text { Difference } \\
\text { in Abs. } \\
\text { Latitude }\end{array}$} & \multirow[b]{2}{*}{$\begin{array}{c}\text { (5) } \\
\text { Adding } \\
\text { Abs. } \\
\text { Difference } \\
\text { in } \% \text { of } \\
\text { Area in } \\
\text { Tropics and } \\
\text { Sub-Tropics }\end{array}$} \\
\hline & & & & & \\
\hline & $\begin{array}{l}\text { SW's } \\
\text { Regional } \\
\text { Dummy }\end{array}$ & $\begin{array}{l}\text { Climate } \\
\text { control only }\end{array}$ & \multicolumn{3}{|c|}{ Region-by-Region Fixed Effects } \\
\hline \multirow{2}{*}{$\begin{array}{l}F_{S T} \text { genetic distance relative } \\
\text { to the US, weighted }\end{array}$} & $3.292 * * *$ & $6.489 * * *$ & 1.000 & 0.645 & 0.660 \\
\hline & $(1.252)$ & {$[1.165]$} & $(1.141)$ & $(1.135)$ & $(1.130)$ \\
\hline \multirow{2}{*}{ Absolute difference in latitude } & -0.170 & 0.104 & -0.031 & $-0.465^{*}$ & -0.094 \\
\hline & $(0.226)$ & {$[0.264]$} & $(0.258)$ & $(0.279)$ & $(0.262)$ \\
\hline \multirow{2}{*}{ Absolute difference in longitude } & $0.258^{*}$ & -0.02 & $0.467 * *$ & 0.228 & $0.410 * *$ \\
\hline & $(0.146)$ & {$[0.182]$} & $(0.203)$ & $(0.188)$ & $(0.193)$ \\
\hline \multirow{2}{*}{ Geodesic distance (1000s of km) } & -0.027 & -0.014 & -0.041 & -0.008 & -0.036 \\
\hline & $(0.020)$ & {$[0.024]$} & $(0.027)$ & $(0.025)$ & $(0.026)$ \\
\hline \multirow{2}{*}{$=1$ for contiguity } & $-0.339 * * *$ & $-0.580 * * *$ & $-0.359 * * *$ & $-0.318 * * *$ & $-0.339 * * *$ \\
\hline & $(0.068)$ & [0.072] & $(0.070)$ & $(0.067)$ & $(0.068)$ \\
\hline \multirow{2}{*}{$\begin{array}{l}=1 \text { for either country is island } \\
\text { ( } 0 \text { for both are islands) }\end{array}$} & $0.168 * *$ & 0.149 & $0.166^{* *}$ & $0.159^{*}$ & $0.156^{*}$ \\
\hline & $(0.083)$ & {$[0.095]$} & $(0.082)$ & $(0.082)$ & $(0.084)$ \\
\hline \multirow{2}{*}{$\begin{array}{l}=1 \text { for either country is landlocked } \\
(0 \text { for both landlocked })\end{array}$} & $0.161 * *$ & $0.128^{*}$ & $0.135 * *$ & $0.153 * *$ & $0.142 * *$ \\
\hline & $(0.073)$ & {$[0.075]$} & $(0.067)$ & $(0.065)$ & $(0.066)$ \\
\hline \multirow{2}{*}{$\begin{array}{l}=1 \text { if pair shares at least one sea or } \\
\text { ocean }\end{array}$} & $0.106^{*}$ & -0.001 & 0.051 & 0.070 & 0.054 \\
\hline & $(0.054)$ & {$[0.057]$} & $(0.056)$ & $(0.057)$ & $(0.055)$ \\
\hline \multirow{2}{*}{$\begin{array}{l}\text { Absolute difference in absolute } \\
\text { latitude }\end{array}$} & & & & $0.010^{* * *}$ & \\
\hline & & & & $(0.004)$ & \\
\hline \multirow{2}{*}{$\begin{array}{l}\text { Absolute difference in } \% \text { of land } \\
\text { area in tropics and subtropics }\end{array}$} & & $0.190 *$ & & & $0.183 * *$ \\
\hline & & [0.109] & & & $(0.089)$ \\
\hline Observations & 10,296 & 10,296 & 10,296 & 10,296 & 10,296 \\
\hline
\end{tabular}




\section{Fig. 1. Chloropleth Map: Weighted Genetic Fst Distance from the US}

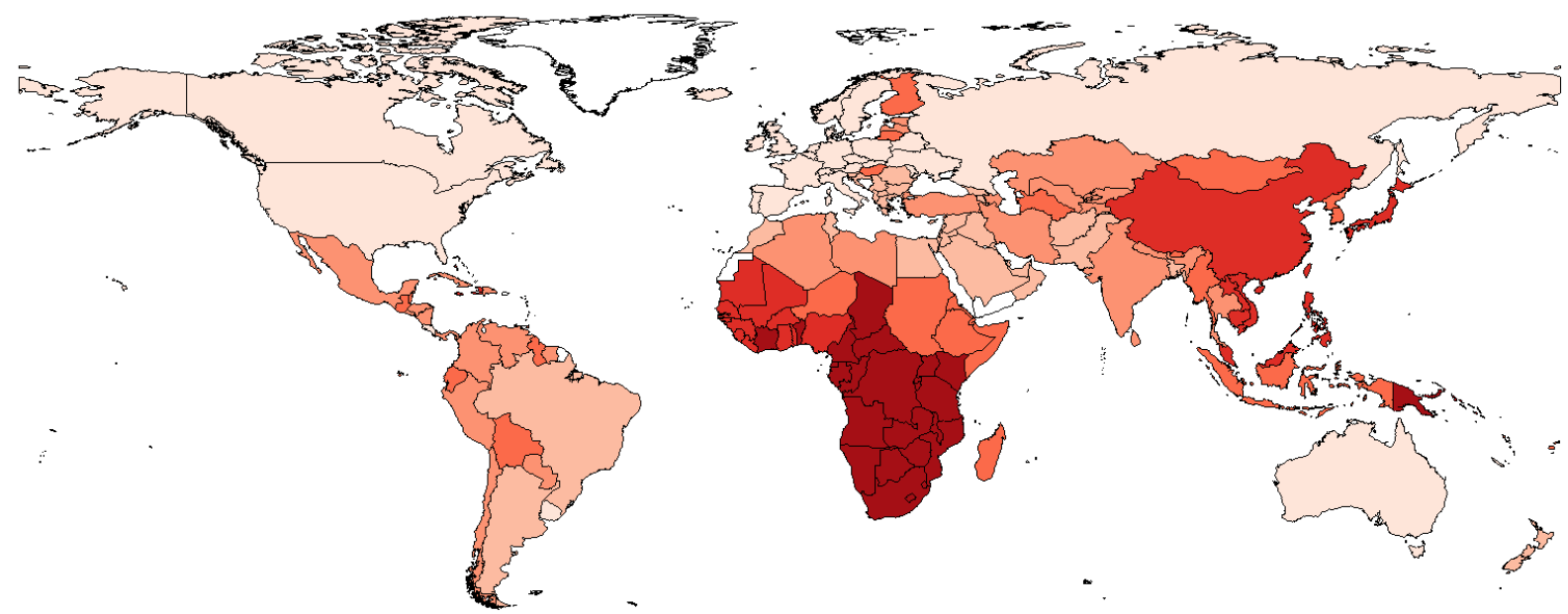

(Darker countries are genetically relatively more distant from the US.)

Fig. 2. Latitudinal Distance from the US vs. Distance from the Equator
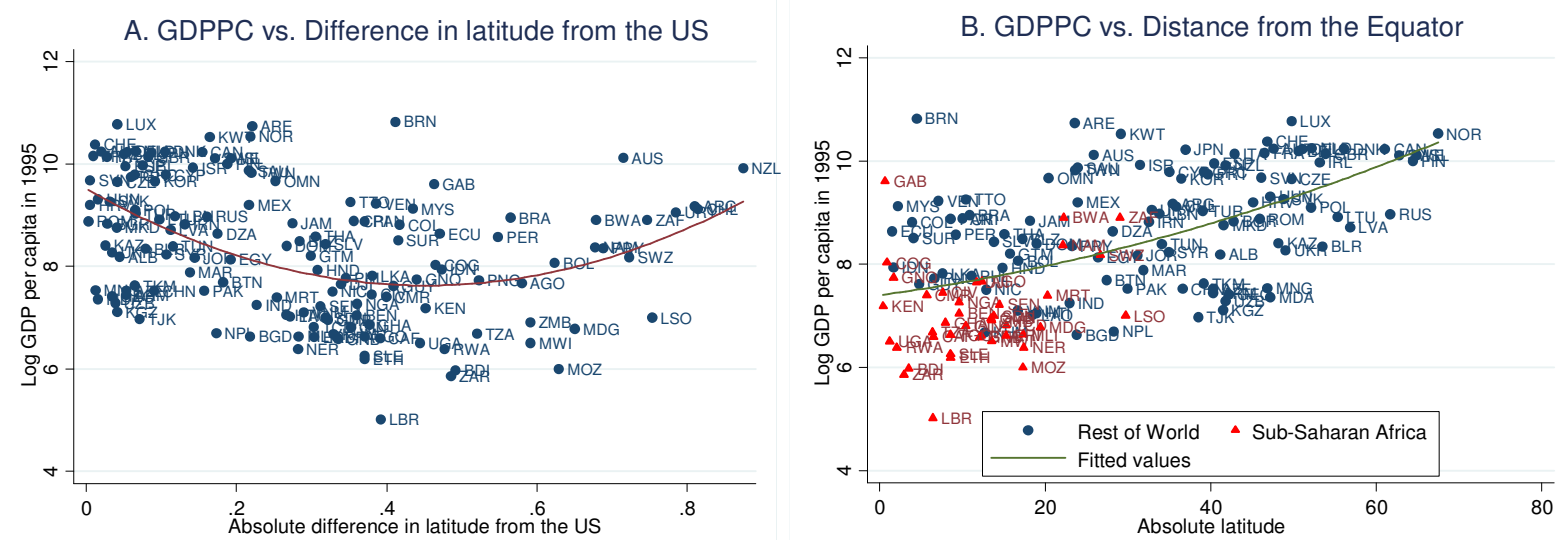
Fig. 3. Income per capita vs. Genetic Distance to the US: Asia and sub-Saharan Africa

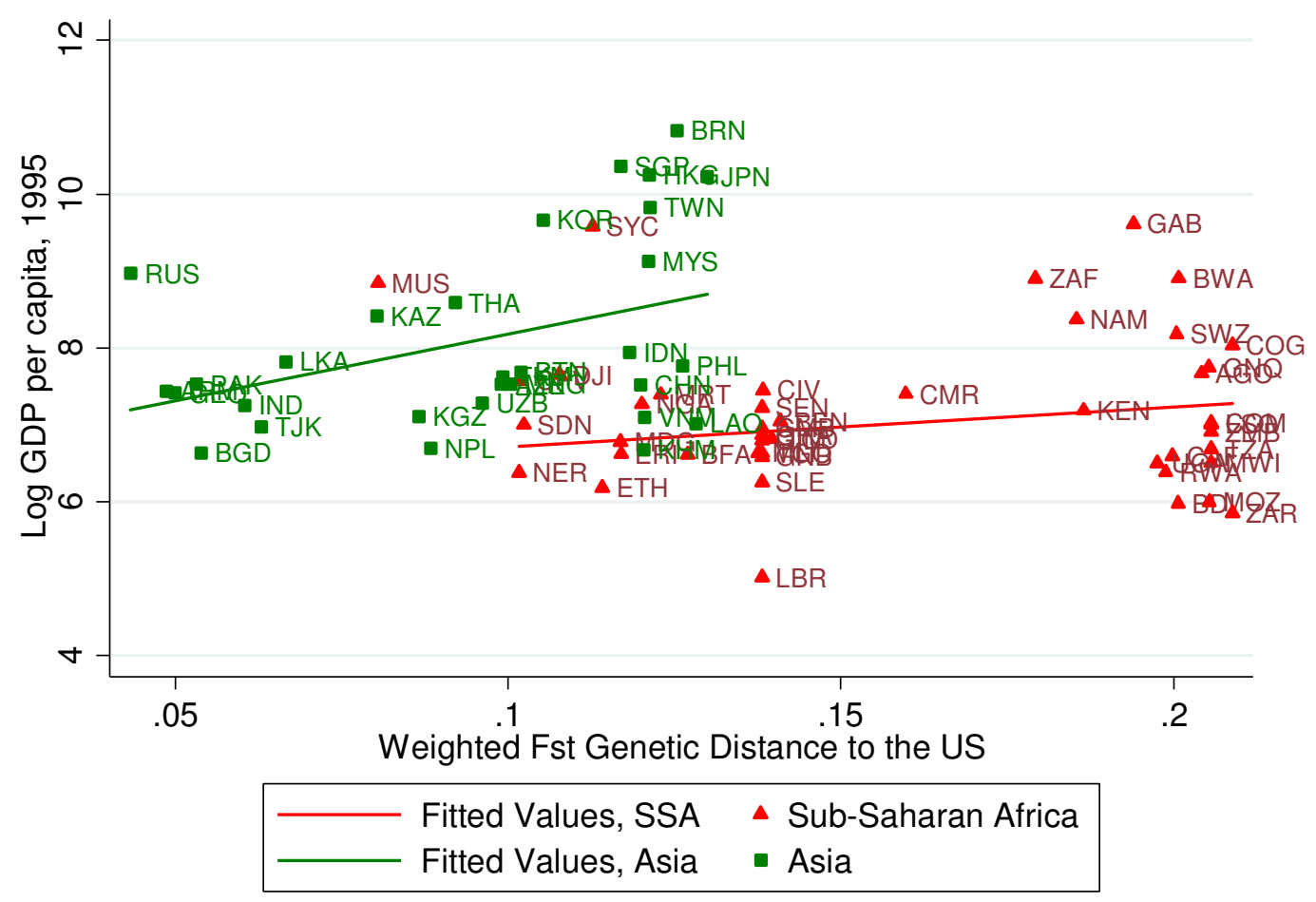

Fig. 4. . Income per capita vs. Genetic Distance to the US: World ex sub-Saharan Africa and Europe

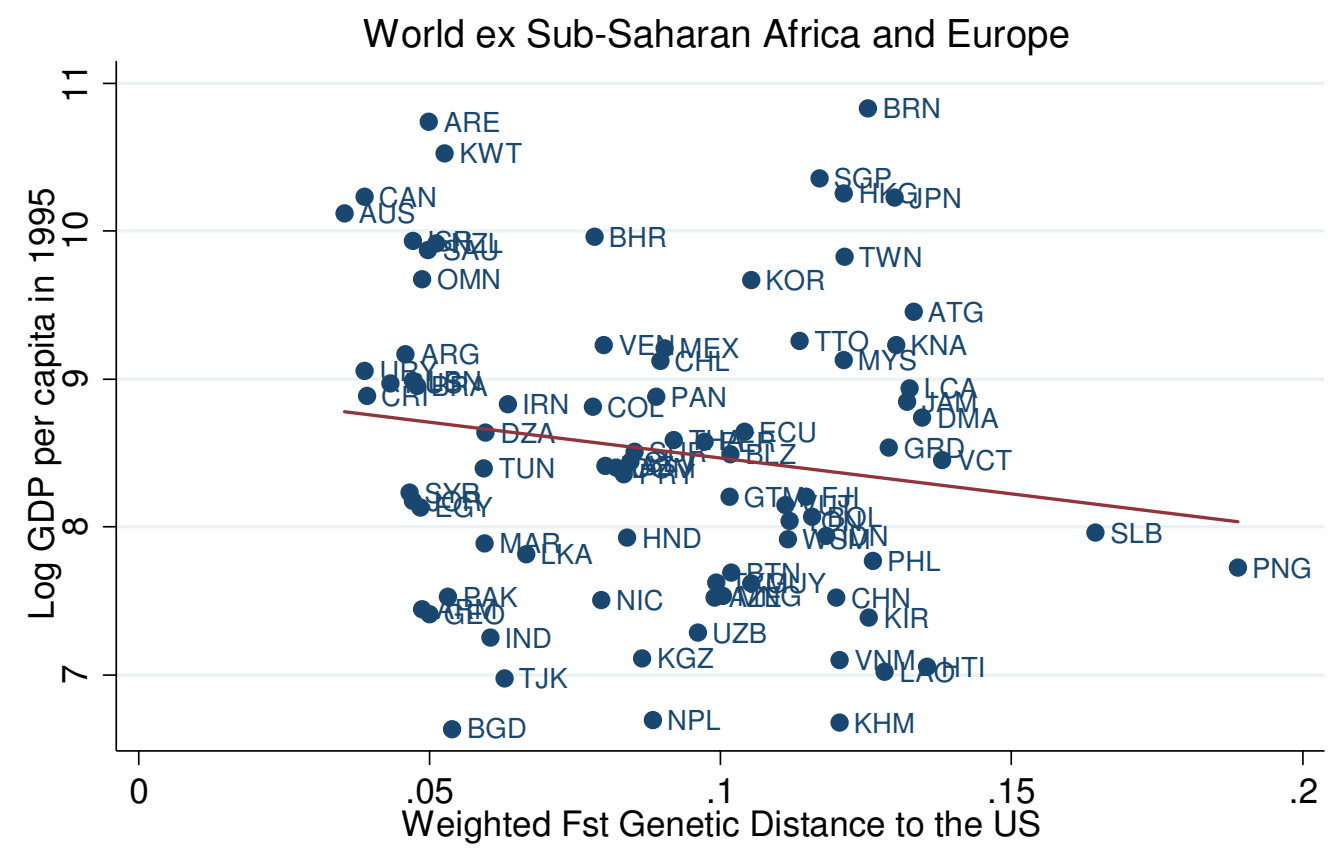

- Actual Values Fitted Values (Slope Not Statistically Signficant 